\title{
PEMANFAATAN LIMBAH ABU MARMER SEBAGAI FILLER TERHADAP KARAKTERISTIK MARSHALL PADA CAMPURAN LAPIS TIPIS ASPAL PASIR (LATASIR) B
}

\author{
Utilization of Marble Ash Waste as Filler to Marshall Charakteristics in A Mixture of \\ Thin Layer of Asphalt Sand (Latasir) B
}

\author{
Andi Syaiful Amal ${ }^{1}$, Wahyuddin Saputra ${ }^{2}$ \\ 1,2Jurusan Teknik Sipil - Fakultas Teknik - Universitas Muhammadiyah Malang \\ Kampus III Jl. Raya Tlogomas No. 246 Tlp. (0341) 464318-319 Pes. 130 Fax. (0341) 460435 \\ e-mail : andiama199@yahoo.co.id
}

\begin{abstract}
Latasir (HRSS) Class B is a mixture intended for roads with light traffic, particularly in areas where coarse aggregate is not available. This mixture has low rutting resistance therefore it should not be used with thick layers, on heavy traffic roads and on elevated areas. The marble ash structure is smooth and can pass filter \# 200 like cement, so it can be studied as an alternative material of filler in asphalt mixture especially latasir class $b$. This research uses Central Quality Control \& Monitoring Unit (CQCMU) method. The purpose of this research is to know the characteristic of marshall on the mixture of class latasir $b$ with filler of marble ash and to know the percentage of optimum content used as substitute of marble ash based on optimum asphalt content. The result of testing of mixture of class latener of class b using filler of marble ash with optimum asphalt content of $9.01 \%$ obtained by percentage of optimum ash content of marble 52,22\%, the Marshall characteristic value are Marshall Stability 800,00 Kg, Marshall Qoutient 1,9 Kg/mm, Air Void 4.9\%, Film Thickness $8.56 \mu \mathrm{m}$.
\end{abstract}

Keywords : Marble Ash; Marshall Characteristics

\begin{abstract}
Abstrak
Latasir (HRSS) Kelas B merupakan campuran yang ditujukan untuk jalan-jalan dengan lalu lintas ringan, khususnya pada daerah dimana agregat kasar tidak tersedia. Campuran ini mempunyai ketahanan alur (rutting) yang rendah oleh sebab itu tidak boleh digunakan dengan lapisan yang tebal, pada jalan dengan lalu lintas berat dan pada daerah tanjakan. Struktur abu marmer yang halus dan dapat lolos saringan \#200 layaknya semen, sehingga dapat dikaji sebagai bahan material alternatif filler dalam campuran aspal khususnya latasir kelas b. Penelitian ini menggunakan metode Central Quality Control \& Monitoring Unit (CQCMU). Tujuan dilakukan penelitian ini adalah untuk mengetahui nilai karakteristik marshall pada campuran latasir kelas b dengan filler abu marmer dan mengetahui presentase kadar optimum yang digunakan sebagai pengganti abu marmer berdasarkan kadar aspal optimum. Hasil pengujian campuran latasir kelas b menggunakan filler abu marmer dengan kadar aspal optimum 9,01\% diperoleh presentase kadar optimum abu marmer sebesar 52,22\% maka diperoleh nilai karakteristik Marshall adalah Marshall Stability 800,00 Kg, Marshall Qoutient 1,9 Kg/mm, Air Void 4,9 \%, Film Thickness 8,56 $\mu \mathrm{m}$.
\end{abstract}

Kata kunci : Abu Marmer; Karakteristik Marshall

\section{PENDAHULUAN}

Pada dasarnya suatu konstruksi perkerasan jalan merupakan perpaduan antara material (kerikil dan pasir) dengan bahan pengikat (semen atau aspal). Perkerasan yang menggunakan bahan aspal untuk bahan pengikat disebut dengan perkerasan lentur, dan perkerasan dengan menggunakan bahan semen sebagai bahan pengikat disebut dengan perkerasan kaku, sedangkan lapisan yang menggabungkan antara perkerasan lentur

dengan perkerasan kaku disebut Perkerasan Komposit.

Jenis beton aspal campuran panas yang digunakan di Indonesia umumnya adalah perkerasan campuran aspal jenis lapisan tipis aspal pasir (Sukirman, Silvia,2003). Latasir ( lapisan tipis aspal pasir ) adalah beton aspal untuk jalan-jalan dengan lalu lintas ringan, khususnya dimana agregat kasar tidak atau sulit diperoleh. Lapisan ini mempunyai 
ketahanan alur (rutting) yang rendah, oleh karena itu tidak diperkenankan digunakan untuk daerah berlalu lintas berat atau daerah tanjakan. Latasir A dikenal dengan nama HRSS-A atau SS-A dengan tebal minimumnya adalah $1,5 \mathrm{~cm}$. Sementara latasir B dikenal dengan nama HRSS-B atau SS-B dengan tebal minimumnya adalah $2 \mathrm{~cm}$ ( Dirjen Bina Marga, 1998 ).

Tulungagung dikenal sebagai kota dengan berbagai potensi usahanya, terutama usaha batu marmer, batu marmer merupakan salah satu jenis batuan metamorf, dimana proses terbentuknya diakibatkan oleh proses metamorfosis batu kapur atau batu gamping. Batu marmer seringkali kita temukan sebagai batu yang menghiasi rumah, lantai, dinding, bahkan furniture seperti meja, bangku, dan lain sebagainya. Di Desa Besole Kecamatan Campurdarat-Tulungagung, Jawa Timur terdapat \pm 150 unit home industri sementara di Desa Gamping Kecamatan CampurdaratTulungagung, Jawa Timur tedapat 201 unit yang terdiri dari 1 industri besar dan 199 unit sedang dan menengah (home industri). Kedua desa ini merupakan desa penghasil produksi marmer yang sudah terkenal baik di dalam negeri maupun ke mancanegara.

Limbah serbuk marmer merupakan limbah yang dihasilkan pada saat proses pemotongan marmer menggunakan mesin gergaji khusus dengan menggunakan air sebagai pendingin alat pemotongan tersebut. Pada saat proses pemotongan batu marmer, limbah serbuk marmer yang dihasilkan diendapkan terlebih dahulu di dalam bak berukuran $\pm 2 \times 2 \times 2 \mathrm{~m}$, setelah penuh yang membutuhkan waktu \pm 1 minggu barulah limbah serbuk marmer tersebut dikuras menggunakan pompa untuk kemudian dikeringkan. Setelah kering digiling kembali untuk menghasilkan abu marmer yang benar benar halus.

Dalam sekali produksi volume limbah serbuk marmer yang dihasilkan diperkirakan mencapai 5-10\%. Jika per-harinya home industri pemotongan marmer memproduksi $1000 \mathrm{~kg} /$ hari maka volume limbah yang dihasilkan sekitar $50 \mathrm{~kg}-100 \mathrm{~kg} / \mathrm{hari}$, dalam seminggu bisa mencapai 300 kg-600 $\mathrm{kg} /$ minggu, dalam 1 bulan bisa mencapai $1300 \mathrm{~kg}-2600 \mathrm{~kg} / \mathrm{bulan}$, dan dalam sebulan saja sudah menghasilkan $\pm 1,3-2,6$ ton limbah serbuk marmer dan itu hanya 1 home industri bagaimana dengan home industri yang lainnya. Limbah serbuk marmer yang sudah diolah menjadi abu marmer ini kemudian dikemas ke dalam karung untuk dijual di toko bangunan, limbah ini hanya digunakan sebagai bahan bangunan saja. Harga limbah abu marmer ini mulai dari Rp.10,000 sampai Rp.15,000 perkarungnya, jika dibandingkan dengan harga Portland Cement (PC) yang menyentuh Rp.75,000 persak tentu limbah abu marmer sangatlah murah. Pada saat ini filler yang umumnya digunakan sebagai bahan campuran aspal adalah Portland Cement (PC), PC merupakan berbahan alam yang tidak bisa diperbaharui, untuk itu perlu adanya alternatif pemilihan bahan filler yang memenuhi syarat serta mempunyai nilai ekonomis. Salah satunya adalah penggunaan limbah abu marmer sebagai filler. Dengan demikian tujuan dalam penelitian ini adalah untuk mengetahui pengaruh dan berapa presentase kadar opimum abu marmer yang digunakan sebagai bahan pengisi berdasarkan kadar aspal optimum. Dan juga manfaat yang diharapkan adalah sebagai masukan dalam pemanfaatan limbah industri khususnya limbah abu marmer sebagai bahan perkerasan jalan.

\section{Pengertian Perkerasan Jalan}

Sukirman (2003) menjelaskan bahwa, perkerasan jalan merupakan lapisan perkerasan yang terletak diantara lapisan tanah dan roda kendaraan, yang berfungsi untuk memberikan pelayanan kepada sarana transportasi. Fungsi perkerasan adalah untuk memikul beban lalu lintas secara aman dan nyaman, serta sebelum umur rencananya tidak terjadi kerusakan yang berarti. Supaya perkerasan mempunyai daya dukung dan keawetan yang memadai, tetapi juga ekonomis, maka perkerasan jalan dibuat berlapis-lapis. Lapisan paling atas disebut juga sebagai lapis permukaan, merupakan lapisan yang paling baik mutunya. Di bawahnya terdapat lapisan fondasi, yang diletakan di atas tanah dasar yang telah dipadatkan.

Pada umumnya pembangunan jalan berdasarkan bahan pengikat. Kontruksi perkerasan jalan dapat dibedakan menjadi konstruksi perkerasan lentur, konstruksi perkerasan kaku, Konstruksi perkerasan komposit. 


\section{Perkerasan Latasir Kelas B}

Menurut Dirjen Bina Marga (1998), Latasir (HRSS) Kelas A dan B merupakan campuran yang ditujukan untuk jalan-jalan dengan lalu lintas ringan, khususnya pada daerah dimana agregat kasar tidak tersedia. Pemilihan kelas A atau B akan tergantung pada gradasi pasir yang digunakan. Campuran latasir B ini mempunyai ketahanan ruting yang rendah oleh sebab itu tidak boleh digunakan dengan lapisan yang tebal, pada jalan dengan lalu lintas berat dan pada daerah tanjakan..

\section{METODE PENELITIAN \\ Lokasi Penelitian}

Penelitian dilaksanakan di Laboratorium Jalan Raya Teknik Sipil Universitas Muhammadiyah Malang.

\section{Bahan Penyusun Perkerasan Campuran Aspal Latasir Kelas B}

Bahan untuk penyusun campuran aspal latasir kelas b terdiri dari : Agregat kasar, agregat halus, bahan pengisi (filler) dan aspal.

\section{Metode Perencanaan Campuran Aspal}

Menurut DPU (2007), serangkaian pengujian di laboratorium diperlukan untuk mendapatkan suatu campuran dengan karakteristik yang memenuhi syarat seperti yang ditentukan dalam spesifikasi. Metode perencanaan campuran yang digunakan :

- Metode Bina Marga, bersumber dari BS594 dan dikembangkan untuk kebutuhan di Indonesia oleh CQCMU (Central Quality Control and Monitoring Unit) Bina Marga. Sehingga lebih dikenal dengan nama metode CQCMU.

\section{Uji-t Dua Sampel Independent}

Menurut Sudjana (1996), sampel dinyatakan tidak berkolerasi antara dua kelompok, bila sampel-sampel yang menjadi objek penelitian dapat dipisahkan secara tegas, artinya anggota sampel kelompok A tidak ada menjadi anggota kelompok B. Untuk menganalisis dua sampel independent dengan jenis data interval / rasio digunakan uji-t dua sampel

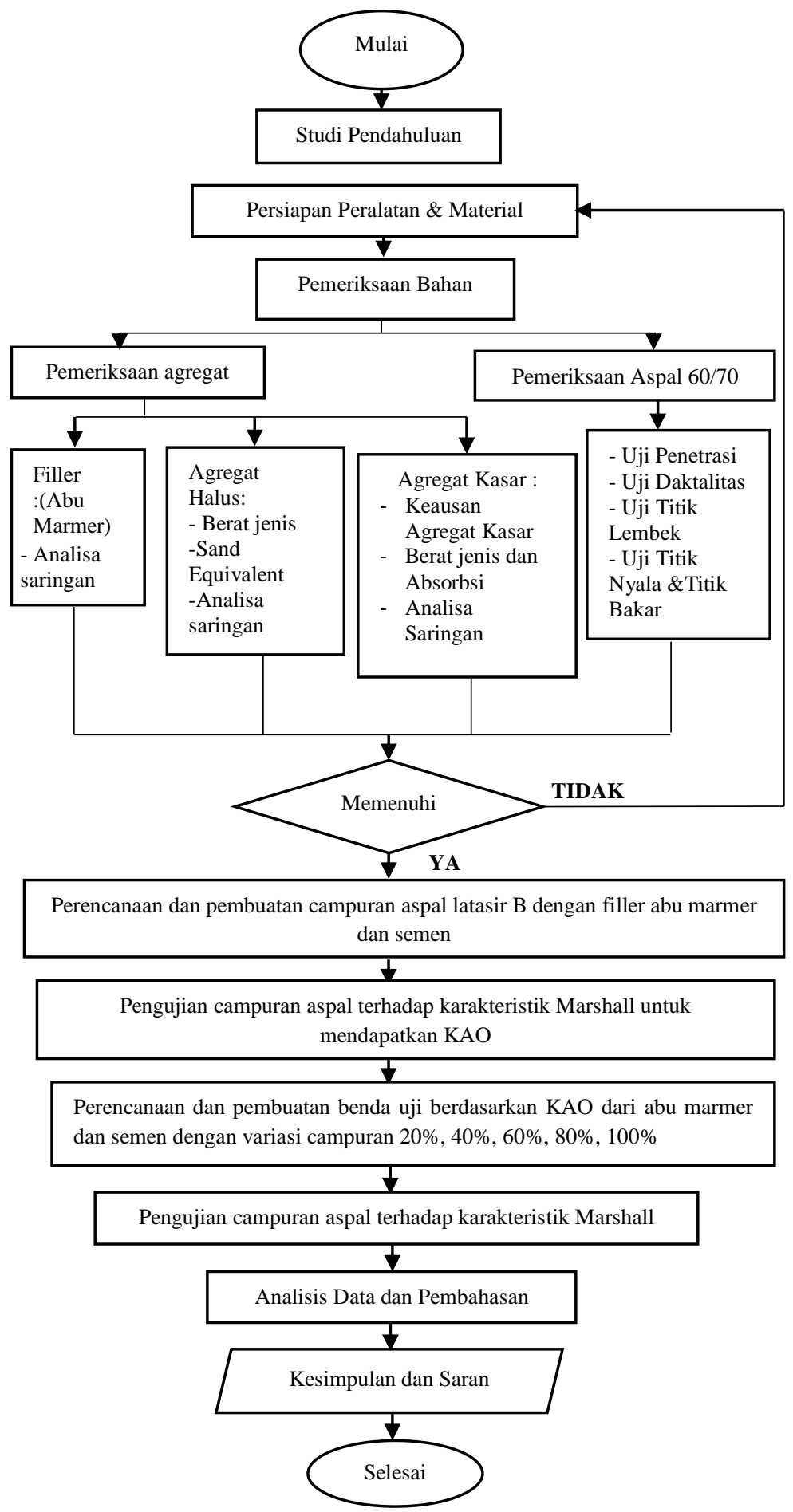

Gambar 1. Diagram Alur Tahapan Penelitian

\section{HASIL DAN PEMBAHASAN}

Hasil Pemeriksaan Bahan

Hasil pemeriksaan agregat kasar, agregat halus, filler dan aspal disajikan pada tabel 1 , tabel 2, tabel 3 dan tabel 4. 
Tabel 1. Hasil Pemeriksaan Agregat Kasar

\begin{tabular}{lcc}
\hline \multicolumn{1}{c}{ Jenis Pemeriksaan } & Syarat & Hasil \\
\hline Keausan agregat kasar & Max $40 \%$ & 15.44 \\
Berat jenis bulk (kering oven) & Min $2.5 \mathrm{gr} / \mathrm{cm}^{3}$ & 2.60 \\
Berat jenis bulk (kering permukaan) & Min $2.5 \mathrm{gr} / \mathrm{cm}^{3}$ & 2.65 \\
Berat jenis semu & Min $2.5 \mathrm{gr} / \mathrm{cm}^{3}$ & 2.74 \\
Penyerapan air & Max 3\% & 2.02 \\
Analisa saringan : & & \\
Gradasi lolos no.3/4 & 100 & 100 \\
Gradasi lolos no.1/2 & $95-100$ & 95.30 \\
Gradasi lolos no.3/8 & $50-100$ & 50.90 \\
Gradasi lolos no.4 & $0-50$ & 12.12 \\
Gradasi lolos no.200 & $0-5$ & 0.18 \\
\hline
\end{tabular}

Sumber : Pemeriksaan di Laboratorium

Tabel 2. Hasil Pemeriksaan Agregat Halus

\begin{tabular}{lccc}
\hline \multicolumn{1}{c}{ Jenis Pemeriksaan } & \multicolumn{1}{c}{ Syarat } & Pasir Alam & Abu Batu \\
\hline Nilai Sand Equivalent (SE) & Min 50\% & 95.79 & 95.79 \\
Berat jenis bulk (kering oven) & Min 2.5 gr/cm & 2.63 & 2.73 \\
Berat jenis bulk (kering permukaan ) & Min 2.5 gr/cm & 2.67 & 2.79 \\
Berat jenis semu & Min 2.5 gr/cm & 2.73 & 2.92 \\
Penyerapan air & Max 3\% & 1.42 & 2.46 \\
Analisa saringan : & & & \\
Gradasi lolos no.3/8 & 100 & 100 & 100 \\
Gradasi lolos no.4 & $72-100$ & 97.63 & 96.77 \\
Gradasi lolos no.8 & $72-100$ & 87.37 & 74.90 \\
Gradasi lolos no.30 & $25-100$ & 51.57 & 31.73 \\
Gradasi lolos no.100 & $0-8$ & 0.23 & 0.30 \\
\hline
\end{tabular}

Sumber : Pemeriksaan di Laboratorium

Tabel 3. Hasil pemeriksaan Filler

\begin{tabular}{lccc}
\hline \multirow{2}{*}{ Jenis Pemeriksaan } & \multirow{2}{*}{ Syarat } & \multicolumn{2}{c}{ Hasil Pemeriksaan } \\
\cline { 3 - 4 } Analisa saringan : & & Abu Marmer & PC \\
No. 200 & $75 \%-100 \%$ & $93.60 \%$ & $100 \%$ \\
\hline \multicolumn{3}{c}{ Sumber : Pemeriksaan di Laboratorium } \\
\end{tabular}

Tabel 4. Hasil Pemeriksaan Aspal

\begin{tabular}{clccc}
\hline No & \multicolumn{1}{c}{ Jenis Pemeriksaan } & Satuan & Syarat & Hasil \\
\hline 1 & Penetrasi & $0.1 \mathrm{~mm}$ & $60-79$ & 66.6 \\
2 & Titik lembek (ring and ball test) & ${ }^{\circ} \mathrm{C}$ & $48-58$ & 50 \\
3 & Titik Nyala (clevland open cup) & ${ }^{\circ} \mathrm{C}$ & Min. 200 & 275 \\
4 & Titik Bakar & ${ }^{\circ} \mathrm{C}$ & Min. 200 & 280 \\
5 & Daktilitas & $\mathrm{Cm}$ & Min.100 & 104 \\
\hline \multicolumn{4}{c}{ Sumber : Pemeriksaan di Laboratorium }
\end{tabular}

\section{Campuran Nominal Latasir Kelas B}

Mengingat kadar aspal syarat minimum campuran latasir kelas B yakni $8,9 \%$ dan diperkirakan kadar aspal optimum berada di antara kadar aspal tersebut. Sedangkan berdasarkan hasil kadar aspal campuran nominal sebesar 8,9\%. Maka campuran nominal dirancang berdasarkan benda uji dengan bahan filler abu marmer dan semen yang direncanakan menggunakan variasi kadar aspal sebesar $\pm 0,25 \%$. Kemudian dilakukan penyesuaian proporsi campuran yang disajikan pada tabel 5 . 
Tabel 5. Penyesuaian Proporsi Campuran Nominal

MATERIAL Campuran Nominal Disesuaikan

\begin{tabular}{cccccccc} 
& 1 & 2 & 3 & 4 & 5 & 6 & 7 \\
\hline & $29.01 \%$ & $29.01 \%$ & $29.01 \%$ & $29.01 \%$ & $29.01 \%$ & $29.01 \%$ & $29.01 \%$ \\
Batu Pecah & $26.91 \%$ & $26.86 \%$ & $26.81 \%$ & $26.76 \%$ & $26.71 \%$ & $26.66 \%$ & $26.61 \%$ \\
Abu Batu & $30.18 \%$ & $30.13 \%$ & $30.08 \%$ & $30.03 \%$ & $29.98 \%$ & $29.93 \%$ & $29.88 \%$ \\
Pasir Alam & $6.68 \%$ & $6.68 \%$ & $6.68 \%$ & $6.68 \%$ & $6.68 \%$ & $6.68 \%$ & $6.68 \%$ \\
Filler & $7.22 \%$ & $7.32 \%$ & $7.42 \%$ & $7.52 \%$ & $7.62 \%$ & $7.72 \%$ & $7.82 \%$ \\
Aspal (A) & $100 \%$ & $100 \%$ & $100 \%$ & $100 \%$ & $100 \%$ & $100 \%$ & $100 \%$ \\
TOTAL & & & & & &
\end{tabular}

Pengujian Campuran Latasir Kelas B Berdasarkan hasil pengujian Marshall campuran latasir kelas B dengan filler Abu marmer dan semen disajikan pada tabel 6 .

Tabel 6. Karakteristik Marshall Campuran Latasir kelas b dengan Filler Abu marmer dan semen

\begin{tabular}{cccccccccc}
\hline \multirow{3}{*}{$\begin{array}{c}\text { Kadar } \\
\text { Aspal }\end{array}$} & $\begin{array}{c}\text { Marshall } \\
\text { Stability } \\
(\mathrm{Kg})\end{array}$ & $\begin{array}{c}\text { Marshall } \\
\text { Quontient } \\
(\mathrm{Kg} / \mathrm{mm})\end{array}$ & $\begin{array}{c}\text { Film } \\
\text { Thickness } \\
(\mu \mathrm{m})\end{array}$ & $\begin{array}{c}\text { Volume } \\
\text { Air Void } \\
(\%)\end{array}$ & $\begin{array}{c}\text { Marshall } \\
\text { Stability } \\
(\mathrm{Kg})\end{array}$ & $\begin{array}{c}\text { Marshall } \\
\text { Quontient } \\
(\mathrm{Kg} / \mathrm{mm})\end{array}$ & $\begin{array}{c}\text { Film } \\
\text { Thickness } \\
(\mu \mathrm{m})\end{array}$ & $\begin{array}{c}\text { Volume } \\
\text { Air Void } \\
(\%)\end{array}$ \\
\hline 8,4 & 885,96 & 4,04 & 7,93 & 4,83 & 714,69 & 2,69 & 7,93 & 13,01 \\
8,4 & 764,31 & 6,46 & 7,93 & 5,28 & 730,44 & 2,31 & 7,93 & 8,06 \\
8,4 & 949,88 & 2,62 & 7,93 & 10,83 & 857 & 2,29 & 7,93 & 9,74 \\
8,65 & 817,69 & 2,51 & 8,18 & 1,95 & 789,13 & 1,82 & 8,18 & 7,88 \\
8,65 & 876,1 & 2,03 & 8,18 & 9,54 & 817,69 & 1,76 & 8,18 & 6,51 \\
8,65 & 876,1 & 2,48 & 8,18 & 3,22 & 832,7 & 2,43 & 8,18 & 10,97 \\
\hline
\end{tabular}

Lanjutan Tabel 6. Karakteristik Marshall Campuran Latasir kelas b dengan Filler Abu marmer dan semen

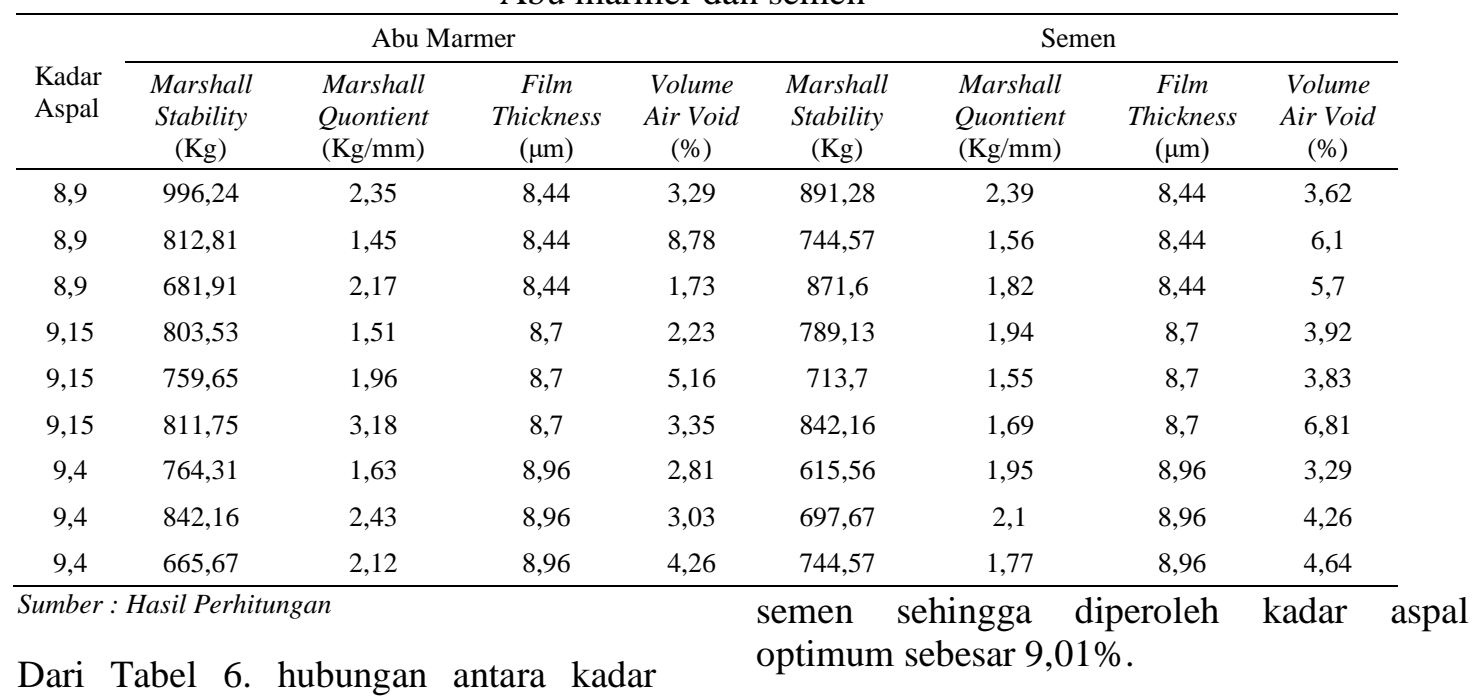
aspal dengan Marshall Stability, Marshall Quotient, Film Thickness, Air Void divisualisasikan pada Gambar 2 untuk filler abu marmer sehingga diperoleh kadar aspal optimum sebesar $8,84 \%$.

Dari Tabel 6. hubungan antara kadar aspal dengan Marshall Stability, Marshall Quotient, Film Thickness, Air Void divisualisasikan pada Gambar 3 untuk filler 


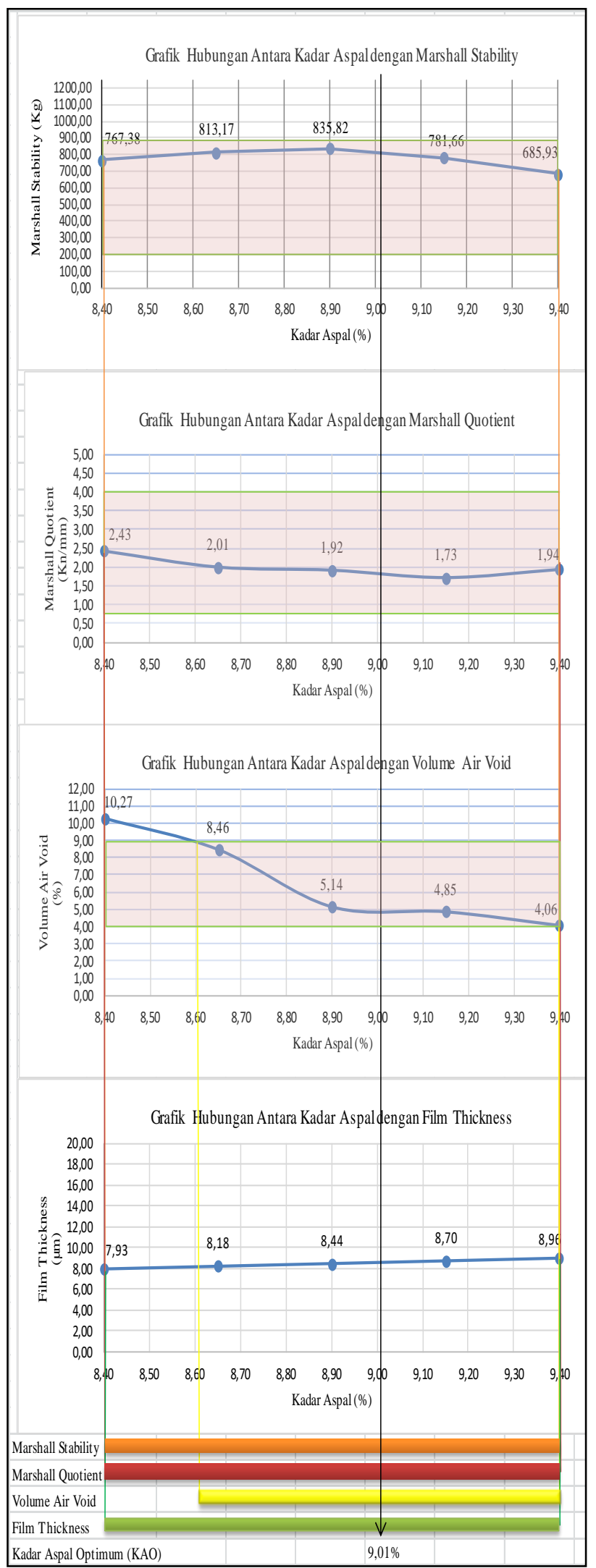

Gambar 2. Grafik Penentuan Kadar Aspal Optimum dengan Filler Abu Marmer

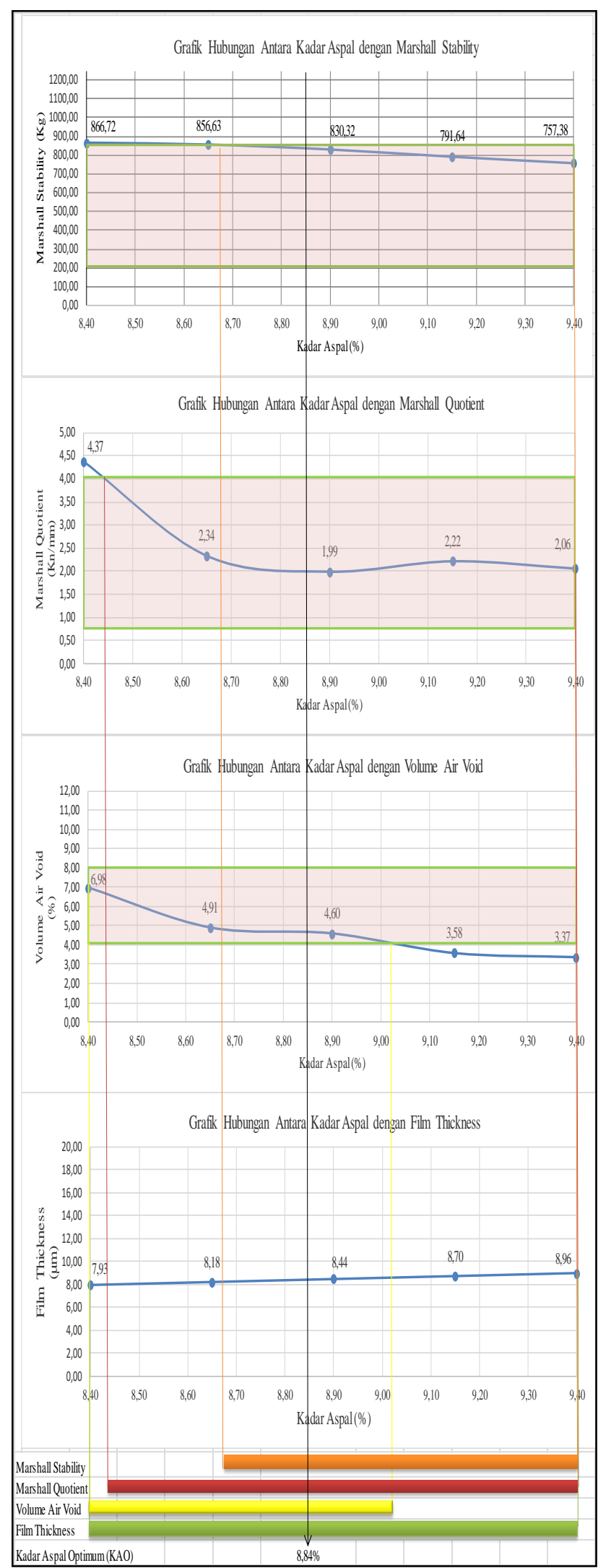

Gambar 3. Grafik Penentuan Kadar Aspal Optimum dengan Filler Semen 


\section{Benda Uji Berdasarkan KAO 8,84\% dan KAO 9,01\%}

Berdasarkan Kadar Aspal Optimum yang didapat maka kemudian direncanakn ulang menggunakan presentase filler dari abu marmer dan semen sebesar $20 \%, 40 \%, 60 \%$, $80 \%$ dan $100 \%$ dengan KAO 8,84\% dan $9,01 \%$. Presentase ini dibuat untuk mengetahui kadar optimum presentase dari pergantian abu marmer berdasarkan KAO $8,84 \%$ dan $9,01 \%$. Semen direncanakan ulang menggunakan presentase pergantian abu marmer $(20 \%, 40 \%, 60 \%, 80 \%$ dan $100 \%)$ karena akan digunakan sebagai bahan untuk uji statistik.

Tabel 7. Karakteristik Marshall Campuran Latasir Kelas B dengan Filler Abu Marmer dan Semen

\begin{tabular}{|c|c|c|c|c|c|c|c|}
\hline \multicolumn{4}{|c|}{ KAO $8,84 \%$ filler abu marmer } & \multicolumn{4}{|c|}{ KAO $9,01 \%$ filler abu marmer } \\
\hline $\begin{array}{c}\text { Marshall } \\
\text { Stability } \\
(\mathrm{kg})\end{array}$ & $\begin{array}{l}\text { Marshall } \\
\text { Quotient } \\
(\mathrm{Kg} / \mathrm{mm})\end{array}$ & $\begin{array}{c}\text { Volume } \\
\text { air Void } \\
(\%)\end{array}$ & $\begin{array}{c}\text { Film } \\
\text { Thicknes } \\
(\mu \mathrm{m})\end{array}$ & $\begin{array}{c}\text { Marshall } \\
\text { Stability } \\
(\mathrm{kg})\end{array}$ & $\begin{array}{l}\text { Marshall } \\
\text { Quotient } \\
(\mathrm{Kg} / \mathrm{mm})\end{array}$ & $\begin{array}{c}\text { Volume } \\
\text { air Void } \\
(\%)\end{array}$ & $\begin{array}{c}\text { Film } \\
\text { Thicknes } \\
(\mu \mathrm{m})\end{array}$ \\
\hline 680,41 & 2,12 & 7,2 & 8,38 & 731,48 & 2,31 & 6,07 & 8,56 \\
\hline 697,67 & 2,32 & 5,57 & 8,38 & 715,93 & 2,3 & 7,49 & 8,56 \\
\hline 780,36 & 2,5 & 5,43 & 8,38 & 817,69 & 2,02 & 8,42 & 8,56 \\
\hline 697,67 & 1,8 & 3,8 & 8,38 & 774,51 & 1,85 & 7,84 & 8,56 \\
\hline 827,07 & 2,49 & 4,67 & 8,38 & 803,53 & 1,89 & 5,12 & 8,56 \\
\hline 780,36 & 1,96 & 6,55 & 8,38 & 848,98 & 2,2 & 3,49 & 8,56 \\
\hline 759,65 & 1,94 & 3,7 & 8,38 & 845,32 & 2,4 & 5,08 & 8,56 \\
\hline 885,96 & 2,06 & 5,52 & 8,38 & 730,44 & 1,57 & 3,62 & 8,56 \\
\hline 714,69 & 2,62 & 3,8 & 8,38 & 759,65 & 1,68 & 5,12 & 8,56 \\
\hline 803,53 & 2,1 & 3,79 & 8,38 & 789,13 & 1,94 & 2,67 & 8,56 \\
\hline 759,65 & 2,22 & 4,31 & 8,38 & 759,65 & 1,69 & 5,28 & 8,56 \\
\hline 811,75 & 2,18 & 3,73 & 8,38 & 857 & 1,8 & 4,58 & 8,56 \\
\hline 817,69 & 2,36 & 2,25 & 8,38 & 789,13 & 1,79 & 2,94 & 8,56 \\
\hline 860,78 & 2,6 & 3,06 & 8,38 & 811,75 & 1,79 & 3,56 & 8,56 \\
\hline 736,37 & 1,81 & 4,46 & 8,38 & 744,57 & 1,88 & 4 & 8,56 \\
\hline
\end{tabular}

Berdasarkan tabel 7 , untuk KAO $8,84 \%$ dengan filler abu marmer hubungan antara kadar aspal dengan Marshall Stability, Marshall Quotient, Film Thickness, Volume Air Void divisualisasikan pada Gambar 4.

Berdasarkan tabel 7, untuk KAO 9,01\% dengan filler abu marmer hubungan antara kadar aspal dengan Marshall Stability,
Marshall Quotient, Film Thickness, Volume Air Void divisualisasikan pada Gambar 5.

Tabel 8. Hasil Kualitas Campuran Latasir Kelas B

\begin{tabular}{lcc}
\hline \multicolumn{1}{c}{ Uraian } & Abu Marmer KAO 8,84\% & Abu Marmer 9,01\% \\
\hline Nilai Marshall Stability & $772,73 \mathrm{Kg}$ & $800,00 \mathrm{Kg}$ \\
Nilai Marshall Quotient & $2,08 \mathrm{Kn} / \mathrm{mm}$ & $1,9 \mathrm{Kn} / \mathrm{mm}$ \\
Nilai Volume Air Void & $4,55 \%$ & $4,90 \%$ \\
Nilai Film Thickness & $8,38 \mu \mathrm{m}$ & $8,56 \mu \mathrm{m}$ \\
\hline
\end{tabular}

Sumber : Hasil Perhitungan 


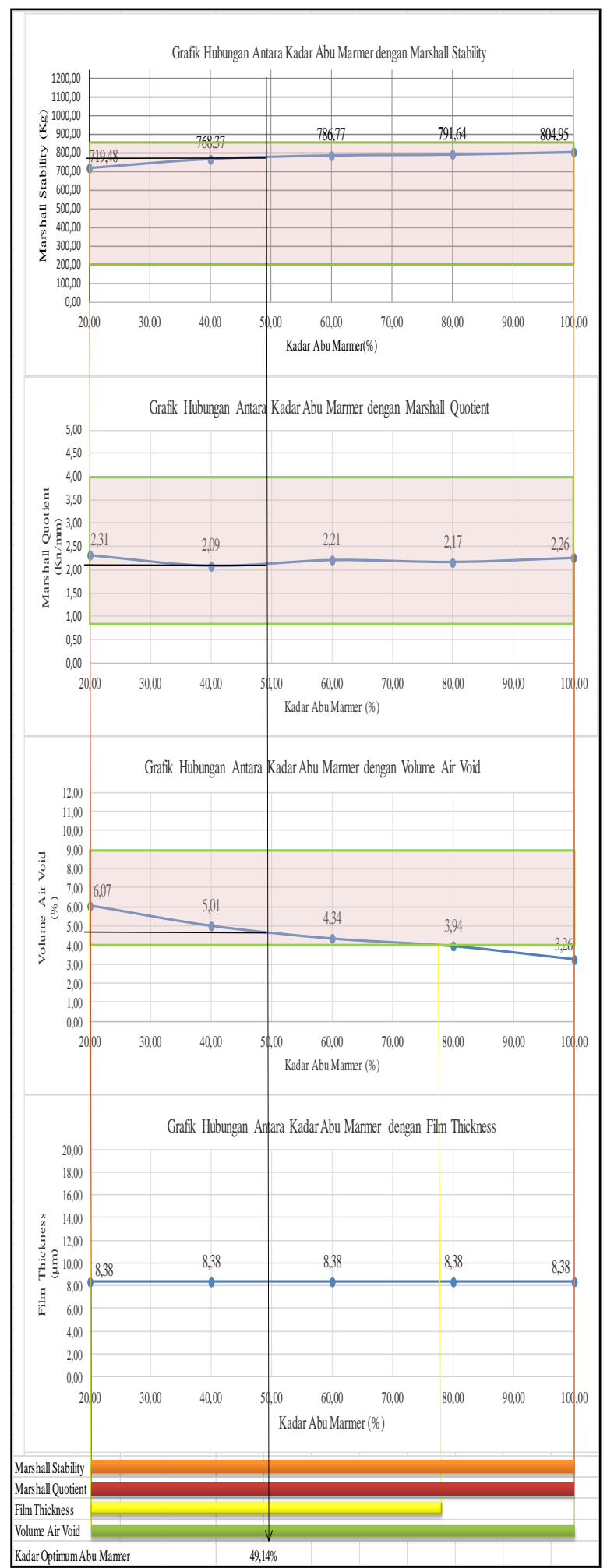

Gambar 4. Grafik Penentuan Kadar Aspal Optimum dengan Filler Abu Marmer

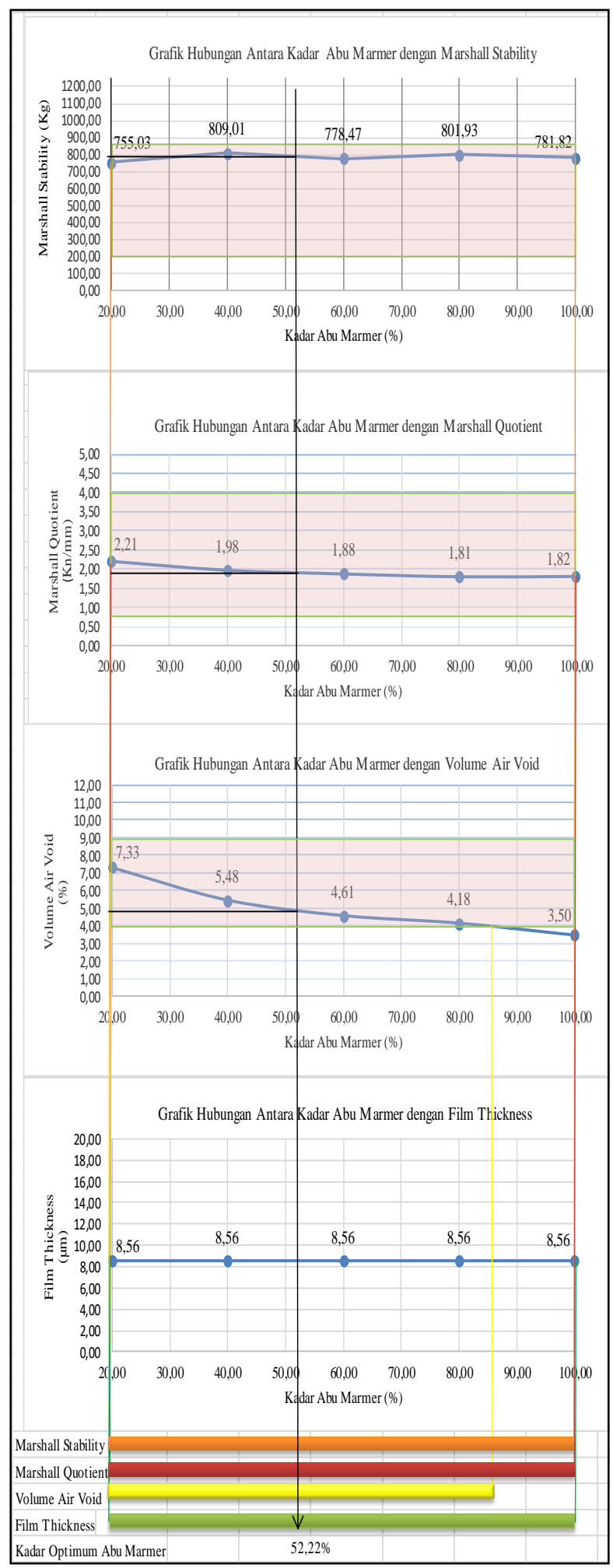

Gambar 5. Grafik Penentuan Kadar Aspal Optimum dengan Filler Abu Marmer 


\section{Tinjauan Uji-t Campuran Latasir Kelas B Campuran Latasir Kelas B dengan KAO $\mathbf{8 , 8 4 \%}$}

- Sampel Independen Marshall Stability Berdasarkan Tabel 9. hasil perhitungan diperoleh nilai rata-rata $\left(\mathrm{X}_{1}\right)$ Marshall Stability filler abu marmer sebesar 774,24 $\mathrm{kg}$, sedangkan untuk filler semen sebesar $761,52 \mathrm{~kg}$. Nilai varian $\left(\mathrm{S}^{2}\right)$ dari masingmasing bahan filler yaitu, untuk abu marmer sebesar 3780,38 dan semen sebesar 2586,55. Sehingga berdasarkan perhitungan diperoleh nilai $t_{\text {hitung }}$ sebesar 0,62 . Dengan taraf signifikan $=0,05$ karena uji 2 sisi, maka nilai tabel pada tabel distribusi $-t$ dengan ketentuan $: \mathrm{db}=\mathrm{n}-2=$ $15-2=13$, sehingga $t_{\text {tabel }}=2,160$. Jika nilai $-\mathrm{t}_{\text {tabel }} \leq \mathrm{t}_{\text {hitung }} \leq \mathrm{t}_{\text {tabel}}$, maka Ho diterima. Ternyata $-2,160<0,62<2,160$ maka Ho diterima. Dengan demikian tidak ada perbedaan nilai statistik antara kedua jenis material dalam nilai Marshall Stablity.

- Sampel Independen Marhsall Quotient Berdasarkan Tabel 10. hasil perhitungan diperoleh nilai rata-rata $\left(\mathrm{X}_{1}\right)$ Marshall Quotient filler abu marmer sebesar 2,21 $\mathrm{kn} / \mathrm{mm}$, sedangkan untuk filler semen sebesar $2,45 \mathrm{~kg} / \mathrm{mm} \mathrm{kg}$. Nilai varian $\left(\mathrm{S}^{2}\right)$ dari masing-masing bahan filler yaitu, untuk abu marmer sebesar 0,07 dan semen sebesar 0,38. Sehingga berdasarkan perhitungan diperoleh nilai $t_{\text {hitung }}$ sebesar 1,39. Dengan taraf signifikan $=0,05$ karena uji 2 sisi, maka nilai tabel pada tabel distribusi $-\mathrm{t}$ dengan ketentuan $: \mathrm{db}=\mathrm{n}-2=$ $15-2=13$, sehingga $t_{\text {tabel }}=2,160$. Jika nilai $-\mathrm{t}_{\text {tabel }} \leq \mathrm{t}_{\text {hitung }} \leq \mathrm{t}_{\text {tabel }}$, maka Ho diterima. Ternyata $-2,160<-1,39<2,160$ maka Ho diterima. Dengan demikian tidak ada perbedaan nilai statistik antara kedua jenis material dalam nilai Marshall Quotient.

- Sampel Independen Volume Air Void Berdasarkan Tabel 11. hasil perhitungan diperoleh nilai rata-rata $\left(\mathrm{X}_{1}\right)$ air void filler abu marmer sebesar 4,52\%, sedangkan untuk filler semen sebesar 4,98. Nilai varian $\left(\mathrm{S}^{2}\right)$ dari masing-masing bahan filler yaitu, untuk abu marmer sebesar 1,75 dan semen sebesar 3,66. Sehingga berdasarkan perhitungan diperoleh nilai $t_{\text {hitung }}$ sebesar 0,77 . Dengan taraf signifikan $=0,05$ karena uji 2 sisi, maka nilai tabel pada tabel distribusi $-t$ dengan ketentuan $: \mathrm{db}=\mathrm{n}-2=$ $15-2=13$, sehingga $t_{\text {tabel }}=2,160$. Jika nilai $-\mathrm{t}_{\text {tabel }} \leq \mathrm{t}_{\text {hitung }} \leq \mathrm{t}_{\text {tabel }}$, maka Ho diterima. Ternyata $-2,160<-0,77<2,160$ maka Ho diterima. Dengan demikian tidak ada perbedaan nilai statistik antara kedua jenis material dalam nilai air void.

Tabel 9. Sampel Independen Marshall Stability KAO $8,84 \%$

\begin{tabular}{ccccc}
\hline No & $\mathrm{X}_{1}$ & $\mathrm{X}_{2}$ & $\left(\mathrm{X}_{1}-\mathrm{X}_{1}\right)^{2}$ & $\left(\mathrm{X}_{2}-\mathrm{X}_{2}\right)^{2}$ \\
\hline 1 & 680,41 & 714,69 & 8804,19 & 2192,74 \\
2 & 697,67 & 744,57 & 5863,07 & 287,19 \\
3 & 780,36 & 729,25 & 37,45 & 1041,14 \\
4 & 697,67 & 665,67 & 5863,07 & 9186,58 \\
5 & 827,07 & 774,51 & 2790,94 & 168,83 \\
6 & 780,36 & 803,53 & 37,45 & 1765,12 \\
7 & 759,65 & 767,83 & 212,89 & 39,86 \\
8 & 885,96 & 812,81 & 12481,21 & 2631,01 \\
9 & 714,69 & 681,91 & 3546,28 & 6337,22 \\
10 & 803,53 & 803,53 & 857,87 & 1765,12 \\
11 & 759,65 & 759,65 & 212,89 & 3,48 \\
12 & 811,75 & 774,51 & 1406,95 & 168,83 \\
13 & 817,69 & 817,69 & 1887,84 & 3155,44 \\
14 & 860,78 & 842,16 & 7489,06 & 6503,35 \\
15 & 736,37 & 730,44 & 1434,19 & 965,76 \\
jumlah & 11613,61 & 11422,75 & 52925,33 & 36211,66 \\
Rata-rata & 774,24 & 761,52 & & \\
\hline Sumber $:$ Hasil Perhitungan & & & \\
Keterangan : & \multicolumn{5}{|l}{ Stability dari abu marmer } & & \\
$\mathrm{X}_{1}=$ Marshall Stars & \\
$\mathrm{X}_{2}=$ Marshall Stability dari semen & &
\end{tabular}

Tabel 10. Sampel independen Marshall Quotient KAO 8,84\%

\begin{tabular}{ccccc}
\hline No & $\mathrm{X}_{1}$ & $\mathrm{X}_{2}$ & $\left(\mathrm{X}_{1}-\mathrm{X}_{1}\right)^{2}$ & $\left(\mathrm{X}_{2}-\mathrm{X}_{2}\right)^{2}$ \\
\hline 1 & 2,12 & 1,76 & 0,01 & 0,47 \\
2 & 2,32 & 2,46 & 0,01 & 0 \\
3 & 2,5 & 2,69 & 0,09 & 0,06 \\
4 & 1,8 & 2,37 & 0,16 & 0,01 \\
5 & 2,49 & 2,87 & 0,08 & 0,18 \\
6 & 1,96 & 1,92 & 0,06 & 0,28 \\
7 & 1,94 & 1,96 & 0,07 & 0,24 \\
8 & 2,06 & 2,04 & 0,02 & 0,17 \\
9 & 2,62 & 2,5 & 0,17 & 0 \\
10 & 2,1 & 3,84 & 0,01 & 1,94 \\
11 & 2,22 & 2,22 & 0 & 0,05 \\
12 & 2,18 & 2,08 & 0 & 0,13 \\
13 & 2,36 & 2,36 & 0,02 & 0,01 \\
14 & 2,6 & 3,67 & 0,16 & 1,5 \\
15 & 1,81 & 1,96 & 0,16 & 0,24 \\
jumlah & 33,08 & 36,7 & 1,02 & 5,27 \\
Rata-rata & 2,21 & 2,45 & & \\
\hline
\end{tabular}

Sumber : Hasil Perhitungan

Keterangan :

$\mathrm{X}_{1}=$ Marshall Quotient dari abu marmer

$\mathrm{X}_{2}=$ Marshall Quotient dari semen 
Tabel 11. Sampel Independen Air Void KAO

\begin{tabular}{ccccc}
\multicolumn{5}{c}{$8,84 \%$} \\
\hline No & $\mathrm{X}_{1}$ & $\mathrm{X}_{2}$ & $\left(\mathrm{X}_{1}-\mathrm{X}_{1}\right)^{2}$ & $\left(\mathrm{X}_{2}-\mathrm{X}_{2}\right)^{2}$ \\
\hline 1 & 7,2 & 10,19 & 7,17 & 27,12 \\
2 & 5,57 & 2,72 & 1,1 & 5,12 \\
3 & 5,43 & 6,7 & 0,82 & 2,95 \\
4 & 3,8 & 5,86 & 0,52 & 0,77 \\
5 & 4,67 & 4,86 & 0,02 & 0,01 \\
6 & 6,55 & 6,55 & 4,11 & 2,46 \\
7 & 3,7 & 3,7 & 0,68 & 1,64 \\
8 & 5,52 & 5,52 & 0,99 & 0,29 \\
9 & 3,8 & 5,72 & 0,52 & 0,54 \\
10 & 3,79 & 3,04 & 0,54 & 3,77 \\
11 & 4,31 & 4,31 & 0,05 & 0,45 \\
12 & 3,73 & 4,67 & 0,63 & 0,1 \\
13 & 2,25 & 4,13 & 5,17 & 0,73 \\
14 & 3,06 & 3,17 & 2,14 & 3,28 \\
15 & 4,46 & 3,59 & 0,004 & 1,94 \\
jumlah & 67,84 & 74,73 & 24,45 & 51,18 \\
Rata-rata & 4,52 & 4,98 & & \\
\hline Sur : & & &
\end{tabular}

Sumber : Hasil Perhitungan

Keterangan :

$\mathrm{X}_{1}=$ Volume Air Void dari abu marmer

$\mathrm{X}_{2}=$ Volume Air Void dari semen

\section{Campuran Latasir Kelas B dengan KAO $\mathbf{9 , 0 1 \%}$}

- Sampel Independen Marshall Stability

Tabel 12. Sampel Independen Marshall Stability KAO 9,01\%

\begin{tabular}{ccccc}
\hline No & $\mathrm{X}_{1}$ & $\mathrm{X}_{2}$ & $\left(\mathrm{X}_{1}-\mathrm{X}_{1}\right)^{2}$ & $\left(\mathrm{X}_{2}-\mathrm{X}_{2}\right)^{2}$ \\
\hline 1 & 731,48 & 764,31 & 2891,28 & 1374,43 \\
2 & 715,93 & 715,93 & 4805,35 & 7302,27 \\
3 & 817,69 & 857 & 1052,31 & 3093,21 \\
4 & 774,51 & 789,13 & 115,36 & 150,14 \\
5 & 803,53 & 817,69 & 334,13 & 265,91 \\
6 & 848,98 & 832,7 & 4061,43 & 980,73 \\
7 & 845,32 & 860,78 & 3608,32 & 3527,96 \\
8 & 730,44 & 744,57 & 3004,21 & 3227,75 \\
9 & 759,65 & 857 & 655,39 & 3093,21 \\
10 & 789,13 & 789,13 & 15,05 & 150,14 \\
11 & 759,65 & 744,57 & 655,39 & 3227,75 \\
12 & 857 & 842,16 & 5147,97 & 1662,74 \\
13 & 789,13 & 789,13 & 15,05 & 150,14 \\
14 & 811,75 & 857 & 702,21 & 3093,21 \\
15 & 744,57 & 759,65 & 1654,92 & 1741,67 \\
jumlah & 11778,76 & 12020,75 & 28718,39 & 33041,3 \\
Rata- & 785,25 & 801,38 & & \\
rata & & & & \\
\hline
\end{tabular}

Sumber : Hasil Perhitungan

Keterangan :

$\mathrm{X}_{1}=$ Marshall Stability dari abu marmer

$\mathrm{X}_{2}=$ Marshall Stability dari semen
Berdasarkan Tabel 12. hasil perhitungan diperoleh nilai rata-rata $\left(\mathrm{X}_{1}\right)$ Marshall Stability filler abu marmer sebesar 785,25 kg, sedangkan untuk filler semen sebesar 801,38 kg. Nilai varian $\left(\mathrm{S}^{2}\right)$ dari masing-masing bahan filler yaitu, untuk abu marmer sebesar 2051,31 dan semen sebesar 2360,09. Sehingga berdasarkan perhitungan diperoleh nilai $t_{\text {hitung }}$ sebesar -0,94. Dengan taraf signifikan $=0,05$ karena uji 2 sisi, maka nilai $t_{\text {tabel }}$ pada tabel distribusi $-\mathrm{t}$ dengan ketentuan $: \mathrm{db}=\mathrm{n}-2=15$ $2=13$, sehingga $t_{\text {tabel }}=2,160$. Jika nilai $-t_{\text {tabel }}$ $\leq \mathrm{t}_{\text {hitung }} \leq \mathrm{t}_{\mathrm{tabel}}$, maka Ho diterima. Ternyata $2,160<-0,94<2,160$ maka Ho diterima. Dengan demikian tidak ada perbedaan nilai statistik antara kedua jenis material dalam nilai Marshall Stablity.

- Sampel Independen Marhsall Quotient

Tabel 13. Sampel independen Marshall Quotient KAO 9,01\%

\begin{tabular}{|c|c|c|c|c|}
\hline No & $\mathrm{X}_{1}$ & $\mathrm{X}_{2}$ & $\left(X_{1}-X_{1}\right)^{2}$ & $\left(X_{2}-X_{2}\right)^{2}$ \\
\hline 1 & 2,31 & 1,97 & 0,14 & 0,3 \\
\hline 2 & 2,3 & 2,38 & 0,13 & 0,02 \\
\hline 3 & 2,02 & 2,62 & 0,01 & 0,01 \\
\hline 4 & 1,85 & 2,68 & 0,01 & 0,03 \\
\hline 5 & 1,89 & 2,92 & 0,003 & 0,16 \\
\hline 6 & 2,2 & 1,9 & 0,07 & 0,38 \\
\hline 7 & 2,4 & 2,2 & 0,21 & 0,1 \\
\hline 8 & 1,57 & 1,87 & 0,14 & 0,42 \\
\hline 9 & 1,68 & 3,15 & 0,07 & 0,4 \\
\hline 10 & 1,94 & 3,77 & 0 & 1,57 \\
\hline 11 & 1,69 & 2,21 & 0,06 & 0,1 \\
\hline 12 & 1,8 & 2,26 & 0,02 & 0,07 \\
\hline 13 & 1,79 & 2,28 & 0,02 & 0,06 \\
\hline 14 & 1,79 & 3,73 & 0,02 & 1,47 \\
\hline 15 & 1,88 & 1,84 & 0,004 & 0,46 \\
\hline jumlah & 29,11 & 37,78 & 0,9 & 5,53 \\
\hline Rata-rata & 1,94 & 2,52 & & \\
\hline $\begin{array}{l}\text { Sumber: Has } \\
\text { Keterangan : } \\
\mathrm{X}_{1}=\text { Marshal } \\
\mathrm{X}_{2}=\text { Marshal }\end{array}$ & rhitung & $\begin{array}{l}\text { bu ma } \\
\text { emen }\end{array}$ & & \\
\hline
\end{tabular}

Berdasarkan Tabel 13. hasil perhitungan diperoleh nilai rata-rata $\left(\mathrm{X}_{1}\right)$ Marshall Quotient filler abu marmer sebesar 1,91 $\mathrm{kg} / \mathrm{mm}$, sedangkan untuk filler semen sebesar $2,52 \mathrm{~kg} / \mathrm{mm}$. Nilai varian $\left(\mathrm{S}^{2}\right)$ dari masingmasing bahan filler yaitu, untuk abu marmer sebesar 1,94 dan semen sebesar 2,52. Sehingga berdasarkan perhitungan diperoleh nilai $t_{\text {hitung }}$ sebesar $-3,30$. Dengan taraf signifikan $=0,05$ karena uji 2 sisi, maka nilai $t_{\text {tabel }}$ pada tabel distribusi $-t$ dengan ketentuan : 
$\mathrm{db}=\mathrm{n}-2=15-2=13$, sehingga $t_{\text {tabel }}=2,160$. Jika nilai $-\mathrm{t}_{\text {tabel }} \leq \mathrm{t}_{\text {hitung }} \leq \mathrm{t}_{\text {tabel }}$, maka Ho diterima. Ternyata $-2,160>-3,30<2,160$ maka Ho diterima. Dengan demikian tidak ada perbedaan nilai statistik antara kedua jenis material dalam nilai Marshall Quotient.

- Sampel Independen Air Void

Tabel 14. Sampel Independen Air Void KAO $8,84 \%$

\begin{tabular}{|c|c|c|c|c|}
\hline No & $X_{1}$ & $X_{2}$ & $\left(X_{1}-X_{1}\right)^{2}$ & $\left(\mathrm{X}_{2}-\mathrm{X}_{2}\right)^{2}$ \\
\hline 1 & 6,07 & 7,65 & 1,11 & 7,99 \\
\hline 2 & 7,49 & 5,31 & 6,11 & 0,24 \\
\hline 3 & 8,42 & 6,48 & 11,57 & 2,74 \\
\hline 4 & 7,84 & 5,63 & 7,96 & 0,65 \\
\hline 5 & 5,12 & 4,63 & 0,01 & 0,04 \\
\hline 6 & 3,49 & 6,32 & 2,34 & 2,24 \\
\hline 7 & 5,08 & 3,47 & 0 & 1,83 \\
\hline 8 & 3,62 & 5,29 & 1,96 & 0,22 \\
\hline 9 & 5,12 & 5,49 & 0,01 & 0,44 \\
\hline 10 & 2,67 & 4,02 & 5,52 & 0,65 \\
\hline 11 & 5,28 & 4 & 0,07 & 0,68 \\
\hline 12 & 4,58 & 3,87 & 0,19 & 0,91 \\
\hline 13 & 2,94 & 3,9 & 4,32 & 0,85 \\
\hline 14 & 3,56 & 2,93 & 2,13 & 3,58 \\
\hline 15 & 4 & 3,36 & 1,04 & 2,14 \\
\hline jumlah & 75,28 & 72,35 & 44,32 & 25,2 \\
\hline $\begin{array}{c}\text { Rata- } \\
\text { rata }\end{array}$ & 5,02 & 4,82 & & \\
\hline $\begin{array}{l}\text { Sumber: } \\
\text { Keteranga } \\
\mathrm{X}_{1}=\text { Volur } \\
\mathrm{X}_{2}=\text { Volur }\end{array}$ & $\begin{array}{l}\text { Air Void } \\
\text { Air Void }\end{array}$ & $\begin{array}{l}1 \text { abu me } \\
\text { semen }\end{array}$ & & \\
\hline
\end{tabular}

Berdasarkan hasil perhitungan diperoleh nilai rata-rata $\left(\mathrm{X}_{1}\right)$ air void filler abu marmer sebesar $5,02 \%$, sedangkan untuk filler semen sebesar 4,82 . Nilai varian $\left(\mathrm{S}^{2}\right)$ dari masingmasing bahan filler yaitu, untuk abu marmer sebesar 3,17 dan semen sebesar 1,80. Sehingga berdasarkan perhitungan diperoleh nilai $t_{\text {hitung }}$ sebesar 0,34. Dengan taraf signifikan $=0,05$ karena uji 2 sisi, maka nilai $t_{\text {tabel }}$ pada tabel distribusi $-t$ dengan ketentuan : $\mathrm{db}=\mathrm{n}-2=15-2=13$, sehingga $\mathrm{t}_{\text {tabel }}=2,160$. Jika nilai $-\mathrm{t}_{\text {tabel }} \leq \mathrm{t}_{\text {hitung }} \leq \mathrm{t}_{\text {tabel }}$, maka Ho diterima. Ternyata $-2,160<0,34<2,160$ maka Ho diterima. Dengan demikian tidak ada perbedaan nilai statistik antara kedua jenis material dalam nilai air void.

\section{Pembahasan}

Berdasarkan gambar 5 kualitas campuran marshall dengan menggunakan filler abu marmer dengan KAO $9,01 \%$ secara keseluruhan masuk dalam spesifikasi dan dapat digunakan sebagai bahan campuran aspal khususnya latasir kelas B.

\section{- Marshall Stability}

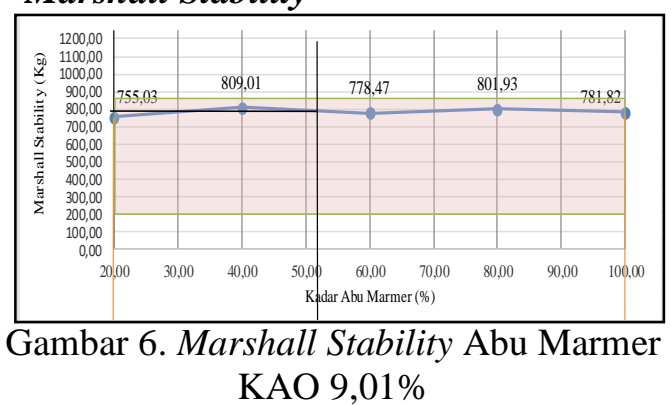

Untuk nilai optimum yang didapatkan pada campuran latasir kelas B abu marmer dengan KAO 9,01\% sebesar 800,00 kg.

Semakin tinggi nilai Marhsall Stability, maka kekuatan dari hasil campuran akan semakin tinggi, begitupun sebaliknya. Nilainya tetap masuk ke dalam persyaratan sifat campuran Marshall Stability latasir kelas b yaitu 200-850 kg. Jadi tidak terdapat masalah pada tingkat kekuatanny

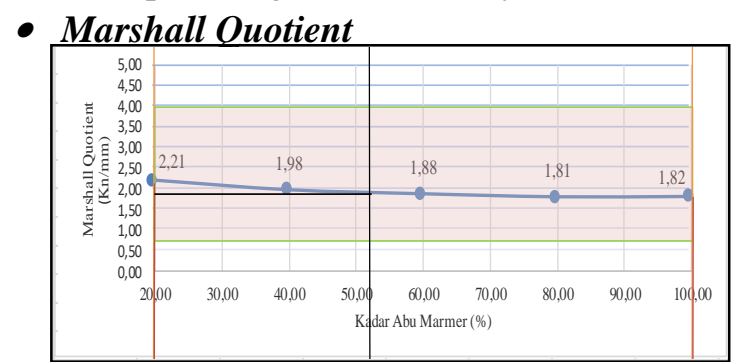

Gambar 7. Marshall Quotient Abu Marmer

KAO $9,01 \%$

Untuk nilai optimum yang didapatkan pada campuran latasir kelas B abu marmer dengan KAO $9,01 \%$ sebesar $1,9 \mathrm{Kn} / \mathrm{mm}$. Apabila faktor Marshall Quotient semakin tinggi nilainya, maka semakin lentur atau flexible dan apabila nilainya rendah, maka jalan tersebut akan menjadi kaku dan mudah patah. Nilainya tetap masuk dalam persyaratan sifat campuran latasir kelas b yaitu $0,8 \mathrm{Kn} / \mathrm{mm}-4,0 \mathrm{Kn} / \mathrm{mm}$. Jadi tidak terdapat masalah pada tingkat kelenturannya.

- Air Void

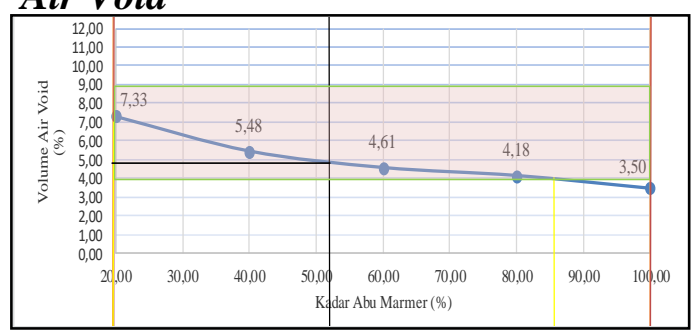

Gambar 8. Air Void Abu Marmer KAO 9,01\% 
Untuk nilai optimum yang didapatkan pada campuran latasir kelas B abu marmer dengan $\mathrm{KAO} 9,01 \%$ sebesar 4,9\%. Apabila faktor Air Void ini semakin tinggi nilainya, maka lapisan tersebut akan mengakibatkan durabilitas dari campuran aspal menurun, sehingga berakibat meningkatnya proses oksidasi aspal yang dapat mempercepat penuaan aspal dan pengelupasan film atau selimut aspal dari permukaan agregat. Namun bila nilainya rendah maka akan mengakibatkan kurangnya ruang gerak antar material saat menerima beban tambahan yang terjadi oleh pengulangan beban lalu lintas. Dalam penelitian ini Air Void masuk dalam persyaratan sifat campuran yaitu 4,0\% - 9,0\%. Jadi tidak terdapat masalah pada rongga udara.

\section{- Film Thickness}

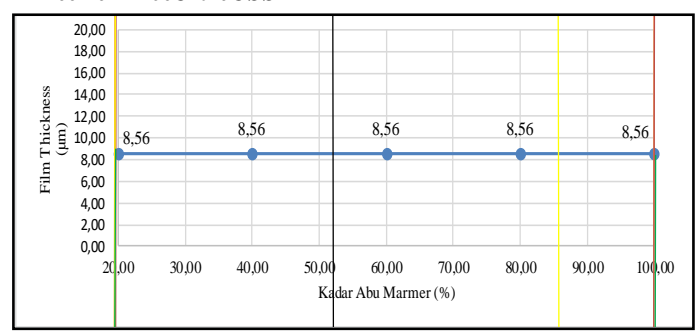

Gambar 9. Film Thickness Abu Marmer KAO

$$
9,01 \%
$$

Untuk nilai optimum yang didapatkan pada campuran latasir kelas $\mathrm{b}$ abu marmer dengan KAO 9,01\% sebesar 8,56 $\mu$ m. Apabila nilai Film Thickness rendah, maka mengakibatkan material mudah lepas dari campuran. Namun apabila nilainya tinggi, campuran akan mengalami bleeding saat temperature meningkat yang akan mengakibatkan jalan semakin licin.

\section{KESIMPULAN DAN SARAN Kesimpulan}

Karakteristik Marshall pada campuran latasir kelas b dengan filler abu marmer berdasarkan kadar aspal optimum 9,01\% adalah Marshall Stability 800,00 Kg, Marshall Quotient 1,9 $\mathrm{Kg} / \mathrm{mm}$, Air Void 4,9\% dan Film Thickness $8,56 \mu \mathrm{m}$. Untuk semua nilai dari karakteristik Marshall masuk dalam persyaratan. Presentase kadar optimum abu marmer sebagai pengganti filler berdasarkan $\mathrm{KAO}$ $9,01 \%$ adalah sebesar $52,22 \%$ dari presentase berat filler.

\section{Saran}

- Dapat digunakan sebagai alternatif bahan pengganti filler pada campuran aspal khususnya latasir kelas $b$.
- Berdasarkan hasil penelitian, perlu adanya pengembangan lebih lanjut mengenai penggunaan abu marmer sebagai bahan pengganti filler pada campuran aspal seperti Laston, ATB dan lainnya.

- Pada saat melakukan penelitian dan pembacaan alat sebaiknya dilakukan dengan cermat untuk meminimalisir kesalahan pada saat pengumpulan data. Hal ini dilakukan agar penelitian bisa lebih akurat.

\section{DAFTAR PUSTAKA}

Amal, Andi Syaiful (2009). Variasi Perendaman Pada Campuran Beton Aspal Terhadap Nilai Stabilitas Marshall. Prosiding Simposium XII Forum Studi Transportasi Antar Perguruan Tinggi, Universitas Kristen Petra Surabaya.

Amal, Andi Syaiful \& Saleh, Chairil. (2015). Pemanfaatan Limbah Batu Marmer Sebagai Pengganti Agregat Kasar Pada Campuran Aspal Beton. Media Teknik Sipil, 13(2), 117-126.

Amal, Andi Syaiful. (2016). Pemanfaatan Pasir Vulkanik Gunung Kelud Sebagai Agregat Halus Pada Campuran ATB Terhadap Nilai Karakteristik Marshall Test. SENTRA 2, Universitas Muhammadiyah Malang.

Anonim. (1998). Bahan Bitumen TB.18 TB.20. Jakarta: Dirjen Bina Marga Departemen Pekerjaan Umum.

Anonim. (1998). Bahan Perkerasan Jalan. Jakarta: Dirjen Bina Marga Departemen Pekerjaan Umum.

Anonim. (2000). Metode Pengujian Bahanbahan Aspal. Jakarta: Yayasan Badan Penerbit Pekerjaan Umum.

Anonim. (2007). Formula Campuran Kerja Asbuton Campuran Beraspal Panas. Jakarta: Departemen Pekerjaan Umum.

Anonim. (2007). Uji Laboratorium Bahan Jalan Untuk Campuran Beraspal. Jakarta: Departemen Pekerjaan Umum.

Aschuri Iman, Yamin RA. (1999). Ketahanan Lelah Campuran Mastik Asbuton Dibandingkan Terhadap Beton Aspal. Jurnal Transportasi, 1(2)

Sukirman, Silvia. (2003). Beton Aspal Campuran Panas. Bandung: Nova. 